\title{
Case report on Plummer Vinson syndrome
}

\author{
Chanukya Vanam*, Durga Prasad Thammisetty
}

Department of Pharmacy Practice, Sri Padmavathi School of Pharmacy, Tiruchanoor, Tirupati, Andhra Pradesh, India

Received: 18 August 2019 Accepted: 13 September 2019

\section{*Correspondence to:}

Dr. Chanukya Vanam, Email: chanukya18@gmail.com

Copyright: (C) the author(s), publisher and licensee Medip Academy. This is an openaccess article distributed under the terms of the Creative Commons Attribution NonCommercial License, which permits unrestricted noncommercial use, distribution, and reproduction in any medium, provided the original work is properly cited.

\begin{abstract}
Plummer Vinson syndrome or Paterson-Brown-Kelly syndrome is a rare disorder is characterized by a triad of iron deficiency anemia, post-cricoid dysphagia and upper oesophageal web. ${ }^{1-4}$ This is a condition that is hypothesized to occur in people with long-term iron-deficiency anemia. It is more prevalent in females than in male patients. This disorder is characterized by iron deficiency anemia, post-cricoid dysphagia and oesophageal webs, symptoms typically progress over a period of six months and often include other systemic effects such as angular cheilitis, glossitis, and spooning of the fingernails. Here we report a case of 38 years female admitted in general medicine female with complaints of breathlessness and tightness of chest relieving after vomiting and had history of anemia, dysphagia insidious in onset and dysphagia associated with solid food over a year on examination patient was found to be gross pallor, angular cheilitis, spoon-shaped nails of fingers and toes. The lab findings were hemoglobin of $7.8 \mathrm{~g} / \mathrm{dl}$, serum ferritin levels 7.23 $\mathrm{ng} / \mathrm{ml}$, vitamin $\mathrm{B}_{12} 175.2 \mathrm{pg} / \mathrm{ml}$ and upper oesophageal endoscopy revealed oesophageal web in the post-cricoid region. Treatment of Plummer Vinson syndrome includes iron supplementation followed by endotracheal dilation if necessary.
\end{abstract}

Keywords: Plummer Vinson syndrome, Iron deficiency anemia, Dysphagia, Oesophageal webs

\section{INTRODUCTION}

Plummer-Vinson syndrome (PVS) was first described by Patterson and Kelly in $1919 .{ }^{1}$ It is a rare syndrome defined by the classic triad of dysphagia, iron-deficiency anemia and oesophageal webs. ${ }^{2}$ Most of the patients are middle-aged women, in the fourth to seventh decade of life but the syndrome has also been described in children and adolescents. ${ }^{2}$ PVS mainly affects the white females whereas it also observed in black women and rarely reported in males. The exact etiopathogenesis of PVS is unclear, but there is an association of iron deficiency anemia with dysphagia. ${ }^{3,4}$ The high turnover rate of the epithelium at the upper digestive tract makes the patient vulnerable to iron deficiency because of the deficiency of iron-dependent enzymes. This reduction of oxidative enzymes of epithelial cells, free radicals stress and DNA damage may lead to mucosal atrophy, web formations and malignant changes. ${ }^{5}$ PVS consists of a triad of dysphagia, iron deficiency anemia, and upper oesophageal webs. Other symptoms include atrophic oral mucosa, cracks or fissuring at the corners of the mouth, glossitis, koilonychia (spoon-shaped nails) or nails that are brittle and break easily. ${ }^{4}$

\section{CASE REPORT}

A 38 year female pale, week, sick looking patient presented with complaints of breathlessness and retrosternal chest pain since one hour history of present illness revealed easy fatigability, palpitations, dysphagia since one year insidious onset gradually progressing to solid foods with odynophagia (painful swallowing) and no complaints of dysphagia to liquids on counseling she 
revealed that dysphagia and chest tightness relieved after vomiting. Her past history had no thyroid disease, diabetes, hypertension, tuberculosis and cerebrovascular attack, personal history shows that she was on a mixed diet, not a smoker or alcoholic.

On examination she was found to be gross anaemic with pallor, koilonychia (spoon shaped nails) of fingers (Figure 1) and toes, angular chelitis (cracks or fissuring at the corners of the mouth) and laboratory investigations shows haemoglobin $(\mathrm{Hb}) 7.8 \mathrm{~g} / \mathrm{dl}$, total count 7700 cumm, Blood urea nitrogen $37 \mathrm{mg} / \mathrm{dl}$, serum creatinine $0.9 \mathrm{mg} / \mathrm{dl}$, total bilirubin $0.9 \mathrm{mg} / \mathrm{dl}$, direct bilirubin 0.3 $\mathrm{mg} / \mathrm{dl}$, serum albumin $3.2 \mathrm{~g} / \mathrm{dl}$, serum protein $6.9 \mathrm{mg} / \mathrm{dl}$, platelets count $4.22 \mathrm{lakh} / \mathrm{cumm}$ and serum iron profile includes serum ferritin $7.3 \mathrm{ng} / \mathrm{ml}$, total iron binding capacity $298.4 \mu \mathrm{g} / \mathrm{dl}$, transferrin $203 \mu \mathrm{g} / \mathrm{dl}$, folate serum $3.03 \mathrm{ng} / \mathrm{dl}$ and upper gastrointestinal endoscopy shows mild oesophageal webs in post cricoid region.

After considering the physical examinations, analyzing the laboratory reports and endoscopy results the clinical condition was diagnosed as Plummer Vinson syndrome.

On first and second day treatment included one packed cell transfusion iron supplements tab. Iron-folic acid 200 $\mathrm{mg}$, tab. vitamin B complex od and tablet vitamin C 500 mg supplements, inj. pantoprazole $40 \mathrm{mg}$ and inj. ondansetron $4 \mathrm{mg}$ i.v. taken from day three iron supplements tablets was changed to syrup and folic acid was given as tab. folic acid $5 \mathrm{mg}$ and on the fourth-day, plan for packed cell transfusion and rest of the therapy was same on the fifth-day and fresh complaints were observed, patient was feeling better and she was advised to continue the therapy for about a week and was asked to return for a check-up.

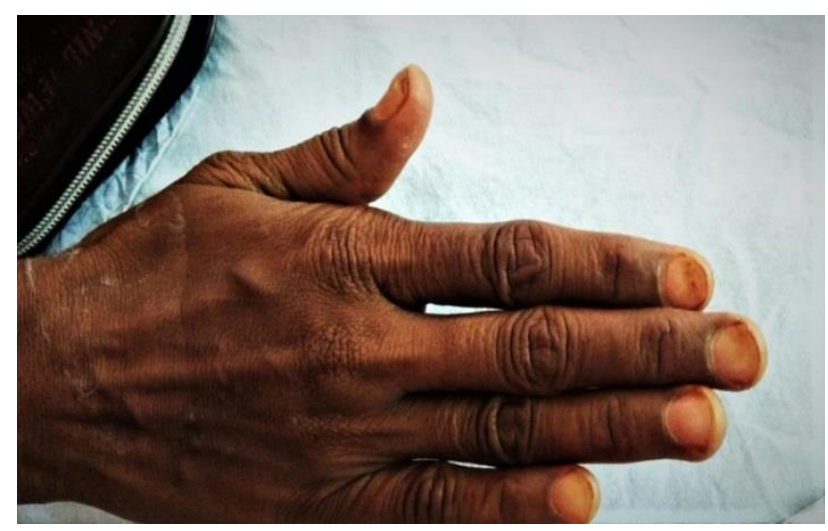

Figure 1: Koilonychia (spoon-shaped nails).

\section{DISCUSSION}

In 1912, Plummer reported that there were some cases of dysphagia associated with severe anemia which had been regarded as a kind of hysteria or neurosis of unknown cause. ${ }^{5}$ Subsequently, Vinson reported that this type of dysphagia has three characteristic manifestations: anemia, dysphagia and atrophic glossitis, and Kelly and Paterson pointed out the high incidence of hypochromic anemia in this disease. ${ }^{6-8}$ Since then syndrome associated with such symptoms has been termed as Plummer-Vinson syndrome or Paterson-Kelly syndrome. The syndrome mainly affects white females, in the 40's to 70 s of life, but some cases of pediatric and adolescent have also been reported. $^{2}$

The predominant clinical features of PVS are an upper esophageal webs, dysphagia, and iron deficiency anemia. ${ }^{2}$ Other oral symptoms like angular cheilitis, early loss of teeth, glossitis and anaemic symptoms like weakness, pallor, fatigue, and tachycardia may dominate the clinical picture.

The pathophysiology of PVS is not clear, but various theories like iron deficiency anemia, malnutrition, genetic predisposition and autoimmune etiologies are postulated. ${ }^{2}$ Among them, iron deficiency anaemia is most widely accepted etiological factor as dysphagia and esophageal webs improve with iron supplementation. ${ }^{2}$ The theory of iron-deficiency anemia based on the rapid losses of irondependent enzymes due to its high cell turnover. As in anemia, there is a reduction of iron-dependent enzymes it causes epithelial atrophy and decreases the repair capacity of the mucosa, it allows the carcinogens and cocarcinogens to act aggressively and predisposes the entire oral cavity and esophageal area to malignancy. ${ }^{9}$ Another theory which has minor importance was vitamin $\mathrm{B}_{6}$ (pyridoxine) and vitamin $\mathrm{B}_{12}$ (cyanocobalamin) deficiency was also believed to contribute to PVS syndrome. ${ }^{1}$. The above case-patient was started with iron supplementation therapy but very few cases have been reported that were responding to iron replenishment. Dysphagia in such settings requires mechanical dilatation in adjunction with iron therapy. In most cases, one session of such dilatation is usually enough for long-term relief but, rarely, multiple sessions may also be warranted.

PVS can be associated with pernicious anemia, thyroiditis or celiac diseases. Celiac disease is one of the recognized causes of chronic iron deficiency and therefore should be considered as an etiological factor in sideropenic dysphagia. ${ }^{11-14}$ PVS has also been identified as a risk factor for developing squamous cell carcinoma of the upper gastrointestinal tract. Three to fifteen percent of the patients with PVS are mostly women between 15-50 years of age, have been reported to develop esophageal or pharyngeal cancer. ${ }^{15,16}$

Diagnosis of PVS is based on the history of the patient, general clinical examination hematological investigations especially like anemic profile and radiological examinations like barium swallow x-ray test of the chest, upper gastrointestinal tract endoscopy. Supplementary investigations like videofluoroscopy, biopsy for histopathological examination might be helpful in some patients. Differential diagnosis of PVS has to be 
performed keeping in view of all the other related causes of dysphagia such as malignant tumors esophagus, benign strictures, spastic motility disorders, scleroderma, diverticula, and gastroesophageal reflux disorders all such conditions have to be evaluated. ${ }^{17,18}$

The initial step in treating PVS is to detect the cause of iron deficiency. In females, it is mostly due to increased menstrual flow and in males, an underlying malignancy should be ruled out. Treatment consists of correcting underlying iron deficiency anemia, iron supplements, and mechanical dilatation of the webs. Many studies have shown that iron supplementation alone can improve the symptoms and no mechanical dilatation was required. ${ }^{19}$ This was true in our case as symptoms improved on iron therapy. Mechanical dilatation of webs can be carried out by endoscopic bougies or pneumatic balloons in single or multiple sessions. Surgery is reserved only for recurring webs. Other rare means of disruption of web include neodymium-doped: yttrium aluminum garnet laser therapy or needle-knife electro incision., ${ }^{2,6,18}$ The prognosis of PVS is good as anemia and dysphagia can be effectively treated by iron therapy and webs by dilatation. The condition gets worsen dramatically if this syndrome is associated with complications like squamous cell carcinoma of the hypopharynx and upper esophagus. Other minor supplementary treatments include the patient should be kept on a nutritious diet to maintain the integrity and maturative potential of the oral epithelium due to its malignant potential. ${ }^{18}$

In this case, the approach has begun with iron supplementation as we observed that patient was feeling better and she was advised to continue the therapy for about a week and was asked to return for the check-up. In the next visit after a month of iron supplementation, the symptoms of dysphagia to solids decreased and the same therapy was continued.

\section{CONCLUSION}

Plummer-Vinson syndrome is due to chronic anemic condition leading to symptoms like dysphagia and oesophageal webs. PVS always remain a diagnostic challenge because of other chances of dysphagia like malignant tumors esophagus, benign strictures, spastic motility disorders, scleroderma, diverticula, and gastroesophageal reflux disorders. Patients with PVS are to be carefully treated in most of the cases iron supplementation alone can improve the symptoms and no mechanical dilatation was required. If dysphagia persists mechanical dilation of the esophagus is performed. In this patient treatment started with iron supplementation and vitamin supplements, the patient was feeling better after she was continued on the same therapy and regular visit has been advised to observe the prognosis of the disease.

Funding: No funding sources Conflict of interest: None declared Ethical approval: Not required

\section{REFERENCES}

1. Paterson Dr. A clinical type of dysphagia. J Laryngol Rhinol Otol, 1919;34:289-91.

2. Novacek G. Plummer-Vinson syndrome. Orphanet $\mathbf{J}$ Rare Dis. 2006;1:36.

3. Bredenkamp JK, Castro DJ, Mickel RA. Importance of iron repletion in the management of PlummerVinson syndrome. Ann Otol Rhinol Laryngol. 1990;99:51-4.

4. Okamura H, Tsutsumi S, Inaki S, Mori T. Esophageal web in Plummer-Vinson syndrome. Laryngoscope. 1988;98:994-8.

5. Donhue-Cornejo A, Guzman-Gastelum DA, Constandse-Cortez D, Cepeda GLA, Escalera CR. Squamous cell carcinoma in the tongue and Plummer-Vinson syndrome- a case report. Rev Odontol Mex. 2011;15:189-92.

6. Vittal K, Pandian SS, Malarkodi T. Plummer-Vinson syndrome: a case report and medical management. IJSS Case Reports Reviews. 2015;2(6):10-3.

7. Plummer HS. Diffuse dilatation of the esophagus without anatomic stenosis (cardiospasm), are port of ninety-one cases. JAMA. 1912;58:2013-5.

8. Vinson PP. Hysterical dysphagus. Minn Med. 1922;5:107-8.

9. Kazemi-Jahromi M, Shahriari-Ahmadi A, Samedanifard SH, Doostmohamadian S, Abdolahpoor E, Allameh SF. The association between hypothyroidism and anemia: a clinical study. Int J Hematol Oncol Stem Cell Res. 2010;4:6-9.

10. Jacobs A, Cavill IA. Pyridoxine and riboflavin status in the Paterson-Kelly syndrome. $\mathrm{Br} \mathrm{J}$ Haematol. 1968;14:153-60.

11. Remacha A, Souto JC, Ortuno F, Zuazu-Jausoro I, Mones J, Roca M. Pernicious anemias with subtle or atypical presentations. Sangre (Barc). 1992;37(2):109-13.

12. Dejmkova H, Pavelka K. An unusual clinical manifestation of secundary Sjogren's syndrome and concomitant Paterson- Kelly syndrome. Clin Rheumatol. 1994;13(2):305-8.

13. Dickey W, McConnell B. Ceilac disease presenting as the Paterson-Brown Kelly (Plummer-Vinson) syndrome. Am J Gastroenterol. 1999;94(2):527-9.

14. Makharia GK, Nandi B, Garg PK, Tandon RK. Plummer-Vinson syndrome: unusual features. Indian J Gastroenterol. 2002;21:74-5.

15. Jones RF, The Patterson-Brown-Kelly Syndrome. Its relationship to iron deficiency and post cricoid carcinoma. J. Laryngol Otol. 1998;75:529-61.

16. Simpson RR. Anemia with dyspahgia; a precancerous condition? Proc R Soc Med. 1997;322:1447-54.

17. Demirci F, Savas MC, Kepkep N, Okan V, Yilmaz M, Büyükberber M. Plummer-vinson syndrome and dilation therapy: a report of two cases. Turk $\mathbf{J}$ Gastroenterol. 2005;16(4):224-7.

18. Samad A, Mohan N, Balaji RV, Augustine D, Patil SG. Oral manifestations of plummer-vinson 
syndrome: a classic report with literature review. J Int Oral Health. 2015;7(3):68-71.

19. Bakshi SS. Plummer vinson syndrome is it common in males?. Arquivos de Gastroenterologia. 2015;52(3):250-2.
Cite this article as: Vanam $\mathrm{C}$, Thammisetty DP. Case report on Plummer Vinson syndrome. Int $\mathrm{J}$ Basic Clin Pharmacol 2019;8:2334-7. 